\title{
Hommage à André Leroi-Gourhan
}

Lettre d'un technicien à ses amis ethnologues

Jean-François Quilici-Pacaud

\section{(2) OpenEdition}

Journals

Édition électronique

URL : https://journals.openedition.org/tc/835

DOI : $10.4000 /$ tc. 835

ISSN : 1952-420X

Éditeur

Éditions de l'EHESS

\section{Édition imprimée}

Date de publication : 1 mars 1988

ISSN : 0248-6016

\section{Référence électronique}

Jean-François Quilici-Pacaud, " Hommage à André Leroi-Gourhan », Techniques \& Culture [En ligne],

10 | 1988, mis en ligne le 23 janvier 2006, consulté le 29 septembre 2022. URL : http://

journals.openedition.org/tc/835; DOI : https://doi.org/10.4000/tc.835

Ce document a été généré automatiquement le 29 septembre 2022.

Tous droits réservés 


\section{Hommage à André Leroi-Gourhan}

Lettre d'un technicien à ses amis ethnologues

Jean-François Quilici-Pacaud 